\title{
EFFECTIVENESS OF THE MONETARY POLICY IMPLEMENTATION IN THE CONTEXT OF CRISIS: USE OF SHORT-TERM INTEREST RATE IN THE CZECH REPUBLIC AND THE EMU
}

\section{Ludmila Bartóková, Júlia Duurčová}

\section{Introduction}

The recent economic crisis and the events that followed, namely the debt crisis, pointed to a number of issues of European Economic and monetary union (EMU), such as particularly persistent asymmetries and differences in development. Due to the high interconnectedness of member countries' economies, it is no longer possible to perceive the problems of one country as isolated, since the negative effects are spread throughout the EMU. For this very reason, economists are starting once again various discussions about the advantages and the possibilities of national monetary policy in influencing macroeconomic developments or in diminishing the negative impact of the crisis.

The Czech Republic, as a candidate country for the Euro adoption, is still able to use its own monetary policy. There are, of course, different views on whether a monetary policy of small and highly open economies of the EU can be described as a separate and independent from the overall development of the EMU, and then to what extent. On the other hand, it is a well-known fact that even a setting of a common monetary policy may not be currently satisfactory to all member states. Today, when most countries are characterised by a high degree of openness, the process of monetary transmission operates faster. [20], [34] The evaluation of this process and its effectiveness in influencing macroeconomic development is possible by examining the operations of monetary policy via selected transmission channels. All of these factors led to our interest in this particular topic.
The paper is focused on the analysis of the transmission processes of monetary policy in the EMU and in one of the accession candidate countries, the Czech Republic. The analysis was focused on the evaluation of the similarity in responses to monetary policy shocks in both the EMU and the Czech Republic. Closer attention was paid to the influence of the shortterm interest rate transmission channel on the price level, the nominal effective exchange rate and the gross domestic product. The effects of interest rate shocks on selected variables were identified by estimating a VAR model. This analysis allows to determine the impulse-response functions that are used to estimate the impacts of interest rate on selected macroeconomic variables. The impacts of shocks were observed for the EMU and the Czech Republic, and the results were compared for the two periods. The aim of this paper is to evaluate the extent of similarity of monetary transmission process via the interest rate transmission channel in case of the EMU and the Czech Republic, taking into account the crisis period.

\section{Overview of the Literature}

During the last decade many important changes occurred in the monetary policy strategies as well as in the monetary policy instruments. This can be seen in the case of traditional transmission channels of monetary policy and their effectiveness, which have varied due to a number of structural changes in the economies as well as due to changing expectations of economic subjects. [29] Nowadays, most central banks use key interest rates in the implementation of their monetary policies. 
This way, they are able to influence inflation expectations of different market subjects and direct them towards desired level of inflation, thereby maintaining the fundamental objective of the scheme based on price stability, such as inflation-targeting regime. [15] However, persisting problems of low economic growth and stagnant economies also forced the ECB and the Czech National Bank (CNB) to use less conventional monetary policy measures. In the case of the Czech Republic, CNB chose to use a heavily expansionary monetary policy oriented on the weakening of the exchange rate in order to stimulate the export performance of the country. The ECB decided to use the instrument of quantitative easing.

Despite general agreement on the significant impact of monetary policy on the real economy, the latest global economic crisis has spurred further the debates on the various mechanisms, transmission channels and time delays. It may also be related to the crisis's extent, due to which, many authors refer to it more as a system one (multifactorial) rather than a cyclic one. [22], [24], [26] Studies on a single monetary policy of the EMU countries suggest that the impact of monetary policy on the real economy in the EMU depends on a number of external factors (economic structure, competitiveness, presence of various shocks, etc.). [29] Impacts of the financial crisis on the transmission mechanism re analysed, for example in the Report on Financial Stability published by the International Monetary Fund [23]. The report compares the operation through the interest rate channel and the effectiveness in influencing short-term and long-term interest rates in the case of the EMU and the USA. According to the Report, the financial crisis marked the transmission from key interest rates to long-term interest rates in the EMU as well as in the US. Badarau, Levieuge [5] analysed in their work the role played by financial heterogeneity of countries in a monetary union and its consequences for the business cycle. The authors showed that the common monetary policy has contributed to the deterioration of cyclical differences of union's countries compared to the situation if these countries were hit with shocks and still had their independent monetary policies. It is therefore necessary to take into account the national characteristics of individual Member States when deciding on changes in the monetary policy, in particular with respect to future possible expansion of the Union. [11], [27] Many of the current works are focused on these EU countries and their monetary transmission in the transformation process. [9] For example Lyziak [28] and Demchuk [14] tested, using VAR method, impacts of the crisis on the effectiveness of monetary policy transmission in the case of Poland. One of the most important findings was that the traditional interest rate channel was the most affected by the crisis. Models of vector autoregression (VAR or VEC) are often used in the analysis of monetary transmission mechanism. A standard VAR approach assumes that the dynamics of the economy can be expressed as a set of macroeconomic variables. Some authors have criticised this approach, arguing that the functioning of the real economy and economic processes cannot be measured by any observable macroeconomic indicators. Despite the critics, these models remain one of the most widely used in modelling of monetary transmission processes. It is because VAR models enable to study and compare the effects of monetary shocks on selected variables in each country. Although monetary conditions as well as transmission processes may be different for various economies, many authors suggest that these differences were not that significant in the 90s. [8], [19] Methods used by these authors were based on different assumptions; nevertheless, they had reached similar results. They showed that the reaction of product to a shock in interest rates was not the same in all EU countries. However, differences in the transmission of monetary policy between countries (such as Germany, France and the United Kingdom) were not too prominent [23]. Angeloni et al. [1] confirmed by using a VAR method that the interest rate channel in the EMU was at that time the most important out of the three monetary policy channels (interest rate channel, asset price channel and credit channel) in the transmission of monetary policy. Their results also showed that the impact of monetary policy on the overall product and the overall price level is the same in the euro area as well as for each of the member countries. The reaction of the product on the unexpected increase in short-term interest rate is only temporary and the prices' response is delayed by four quarters. Jiménez-Rodríguez Morales-Zumaquero and Balázs [25], also Eger, Crespo-Cuaresma and Reininger [18] 
used also a method based on a VAR approach when analysing interest rate, commodity and supply-shocks for ten countries of the Central and Eastern Europe. According to their findings, the responses to the shocks were expressed differently in various countries what they explained by differences in the development and the settings of monetary policies. The transmission mechanism in the case of the Czech Republic in the period 1994-2004 was analysed for example by Arnoštová and Hurník [2]. By using a VAR approach the authors found that unexpected monetary tightening leads to a decrease in product because prices remain inflexible for some time and begin to decline only after about two quarters. The exchange rate, however, reacts by an immediate appreciation. A longer period, covering the crisis, (until 2012) was analysed in the paper by Babecká Kucharčuková et al. [4], where it was confirmed that the transmission via the interest rate transmission channel has been weakened in the years immediately after the crisis.

A VAR model was also used to examine monetary policy actions with regards to the effectiveness of inflation targeting monetary strategy. The causes of deviations of inflation from the CNB targets during the first ten years of the inflation targeting (the period 1998-2007) were studied, again using a VAR model, by Holub. [21] Based on his findings, he concludes that in the short term the shocks in the prices of agricultural producers have been the most important factor of deviations from inflation target. However, in the medium term, the development of the real exchange rate gap clearly became the most important factor. The impact of real interest rates appeared as statistically significant only in the shorter period of 2-3 quarters. Similar conclusions can be found in the analysis of Bisová [10], who observed a stronger and more stable effect of the exchange rate channel on the final target (inflation target) of CNB's monetary policy than in the case of interest rate channel. Other analyses also showed that due to the effects of the crisis it is no longer possible to fully rely on Taylor-type monetary rules. [33] The effectiveness of short-term interest rates becomes problematic especially in times of crisis when the rates may be reduced close to zero levels. As a result, the transmission of the actual macro-economic variables proved to be relatively weak. Many authors suggest that the use of short-term interest rates under fixed monetary rule may be less effective than its management under inflation targeting. They especially highlight the benefits of inflation targeting as a monetary strategy for transparency and greater long-term focus in the common everyday decision-making. [30] Yet, the examination of monetary rules and interest rate transmission mechanism in case of the catching-up countries came to focus relatively recently. However, the authors emphasize that despite the use of inflation targeting, central banks still monitor the evolution of exchange rates. [3], [35]

Economic theory generally assumes that monetary tightening will be followed by a decline of the product and the price level, and shortly thereafter, by the appreciation of the exchange rate. However, some analyses showed that it is also possible to expect the opposite behaviour of the prices and the exchange rate. The reaction of the exchange rate may depend on the monetary regime. The unusual behaviour of exchange rates can also be caused by changes in the exchange rates regime or by currency crises when monetary tightening may lead to an immediate depreciation of the exchange rate instead of an appreciation. This atypical reaction is usually referred to as the "exchange rate puzzle". [2] As for the behaviour of prices, atypical reaction occurs quite often and it is described in a series of works dedicated to the analysis of the impact of monetary policy changes on the price level. Castelnuovo and Surico [12] state that this anomaly was "observed" and labelled as the "price puzzle" firstly by Sims and Eichenbaum. Studies offer several explanations for this problem. One of them is the misidentification of monetary shocks associated with a weak reaction of the interest rate to a given inflation. In other words, what is considered to be a monetary policy shock is in fact a combination of an actual shock and endogenous responses of the monetary policy. [7]

In the following analysis, we therefore tried to apply a vector autoregression model for both the Czech Republic and the EMU to observe and compare the transmission through interest rate transmission channel. We have chosen the GDP, the consumer price index and the exchange rate as basic variables for the model, i.e. variables that central banks typically use when applying their monetary rules. 


\section{Econometric Model-Quantification of the Relationships between Variables}

To verify the existence of relationships between variables, we used a VAR model (Vector autoregression model). This model is often used when examining the effects of monetary policy and the effectiveness of its transmission channels as it equally allows comparing the results obtained for the different countries. A VAR model is usually used to observe the impacts of changes in monetary policy (tightening/easing) on macroeconomic variables such as the product, the price level, etc.

We selected the following variables in order to analyse the interest rate transmission channel: national nominal short-term interest rate (money market 3-month interest rate), gross domestic product at constant prices, nominal effective exchange rate and consumer price index. Similar variables were used e.g. by Arnoštová and Hurník [2], Bisová [10], Holub [21] in their analyses of monetary policy effects.

Unlike some authors in their models ([1], [2], [4]), we decided to omit the monetary aggregates. Many authors have shown that the inclusion respectively omission of these variables in the model will not affect the effects of short-term interest rate shock on the product and prices (e.g. [31]), since the tested shock of monetary tightening is usually followed by a decrease in the money supply.

Based on the theoretical findings on the interest rate transmission mechanism and when neglecting mutual interactions among transmission channels, the relationships between variables can be simply described as follows: a sudden monetary tightening in the form of an increase in the key interest rate is transmitted to short-term interest rates and also to evolution of exchange rate. Consequently, this will influence the activities of economic subjects and should result in declines of the product and the price level after some time.

Our model is based on the following equations:

$$
C Y_{t}=A(L) Y_{t-1}+u_{t}
$$

where $Y_{t}=\left[\begin{array}{llll}i_{r t} & e_{r t}, & y_{t}, & p_{t}\end{array}\right]$ is a $n \times 1$ vector of endogenous non-stationary macroeconomic variables, the $i_{r t}$ is an interest rate, $e_{r t}$ is a nominal effective exchange rate (NEER), $y_{t}$ is a gross domestic product (GDP), $p_{t}$ represents a consumer price index (CPI) and $\mu$ is the vector of constants. $C$ is the $N \times N$ matrix containing all the coefficients describing the current relations between endogenous variables of the model, and $(L)$ is an $N \times N$ polynomial variance-covariance matrix, and $u_{t}$ represents the normalized vector of exogenous shocks that reflects unexplained changes in the development of the endogenous variables in the form of $n \times 1$. Selected ordering of the variables in the vector of endogenous variables takes into account the sequence of transmission of monetary policy from short-term interest rates to other variables.

The reduced form of a VAR model is obtained by multiplying the equation (1) by inverse matrix $C^{-1}$. This operation is necessary because the model represented by equation (1) is not directly observable and structural shocks could not be identified properly. A VAR model described by equation (1) can be modified as follows:

$$
Y_{t}=C^{-1} A(L) Y_{t-1}+C^{-1} u_{t}=B(L) Y_{t-1}+e_{t}
$$

where

$$
\begin{aligned}
& B=C^{-1} A \\
& e_{t}=C^{-1} u_{t}
\end{aligned}
$$

$B(L)$ is a matrix that expresses relation between variables on lagged values and $e_{t}$ represents an $N \times 1$ vector of serially uncorrelated errors of the model.

We estimated and compared two VAR models in order to verify the correctness and accuracy of the results. Both models take into account the constraints arising from the recursive Cholesky decomposition of the residuals. The resulting effects of unexpected shocks on studied endogenous variables are represented by a function of IRF - impulse response function.

However, it is necessary to test the variables for the stationarity of the time series, as well as for the existence of a long-term equilibrium before the applying the model. It is also necessary to check the model for the autocorrelation, the residual heteroscedasticity and the normality. The next part of the paper presents only selected test results. Other results are available from the authors upon request. 


\section{Data and Results}

The model was estimated for two different time periods. A shorter one corresponds to the period from the first quarter of 1999 to the last quarter of 2008 (1999Q1-2008Q4), a longer covers the years 1999 to 2013 (1999Q12013Q3), including the global economic and the debt crises and the events that followed. The use of the same method for periods of various lengths enabled to analyse the impact of aforementioned crises on transmission processes of the monetary policy, namely the effects on product, prices and exchange rate. In our model, we assumed that the crisis negatively affected macroeconomic evolution and disrupted the transmission process of monetary measures to the real macroeconomic variables. As a result, the consequences of monetary tightening were transmitted to the observed variables only partially or with significant delay (as shown for different countries e.g. in [4], [14], [23], [28].

Data used in this analysis were obtained from the databases of the European Central Bank (ECB) [17], the Bank for International Settlements (Bank for International Settlements, BIS) [6], the Eurostat [16], and the Czech National Bank [13]. The model used quarterly data from the years 1999-2013 (60 observations) for the following variables: gross domestic product, the nominal effective exchange rate, price level and short- term interest rates. The analysis was focused on the comparison of indicators in the EMU and the Czech Republic. In the case of GDP time series data were seasonally adjusted in order to eliminate seasonal factors.

\subsection{Evolution of Endogenous Variables}

When constructing the model, we assumed that monetary policy decisions of the central bank and changes of its key interest rates are transmitted to the interest rates on the money market. This suggests that changes in setting of 2-week interest rate for the main refinancing operations are later closely copied by the development of 3-month EURIBOR (Fig. 1). In other words, the evolution of the EURIBOR reflects the changing stance of the ECB. Similarly, in the Czech Republic, changes in the base interest rate, namely 2-week repo rate can be also monitored through the evolution of the PRIBOR, a money market interest rate (Fig. 1). The central bank's key interest rate and the money market interest rate present in both cases a high degree of correlation; thus money market interest rates can be used for estimating changes in monetary policy stance. The same approach (i.e. replacing the 2-week interest rate by 3-month money market interest rate) was used for example by Arnoštová and Hurník [2], also by Babecká Kucharčuková et al. [4].

\section{Fig. 1: Interest rates (\%)}
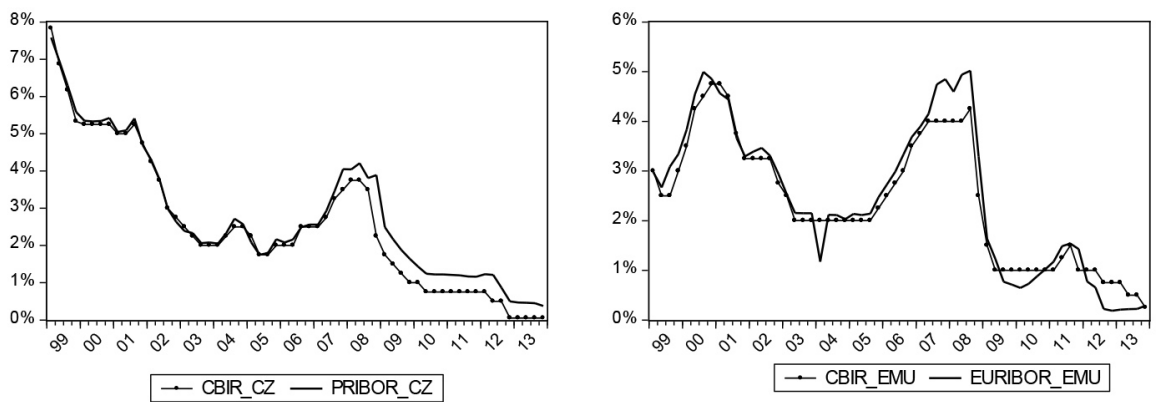

Source: own calculations, ECB [17], CNB [13]

The evolution of endogenous variables in the Czech Republic within the observed period of 1999-2013 was characterised by a considerable volatility (Fig. 2). The reference period can be divided into two basic periods, namely the period of 1999-2008 
and 2008-2013. Up until 2008, there was an apparent long-term growth trend in the GDP accompanied by a strengthening of the nominal effective exchange rate. During this time, macroeconomic situation improved and created conditions for economic growth based on relatively stable economic environment and the positive impact of structural changes. All of this prevented the widening of external imbalances. Increasing performance of the Czech economy positively influenced the final stages of economic transformation, European integration processes, stable monetary environment and a significant inflow of foreign capital. Inflows of capital, together with a high dynamics of economic growth contributed to an appreciation of the nominal effective exchange rate but it did not affect negatively country's foreign competitiveness. The evolution of inflation in the 1990s can be considered relatively volatile until 1999 when it was stabilised. The implementation of the CNB's inflation targets during the first ten years of this strategy was marked by two cases of a significant undershooting of the target in 1998-1999 and 2002-2003. Many economists linked this development to the evolution of the Czech Crown's exchange rate (e.g. [2], [21]). Another significant deviation was observed in 2006-2007. After 2007, a strong growth in consumer prices appeared and it was mainly pushed upwards by the world prices of energy resources as well as by the implementation of selected reform measures in early 2008 . Afterwards, the economic crisis started to affect the overall economic situation. In the second half of 2008 there was a slowdown in economic growth, a decline in inflation and a rising unemployment. The appreciation of the nominal effective exchange rate has slowed down and then the exchange rate depreciated significantly; what has contributed to improving the balance of payments' current account. The positive impact of economic stagnation was reflected in the evolution of inflation which has not exceeded $2 \%$ level since 2010 .

\section{Fig. 2: Evolution of GDP (index, 2005=100), index of consumer prices (index), NEER (index) - CZ}

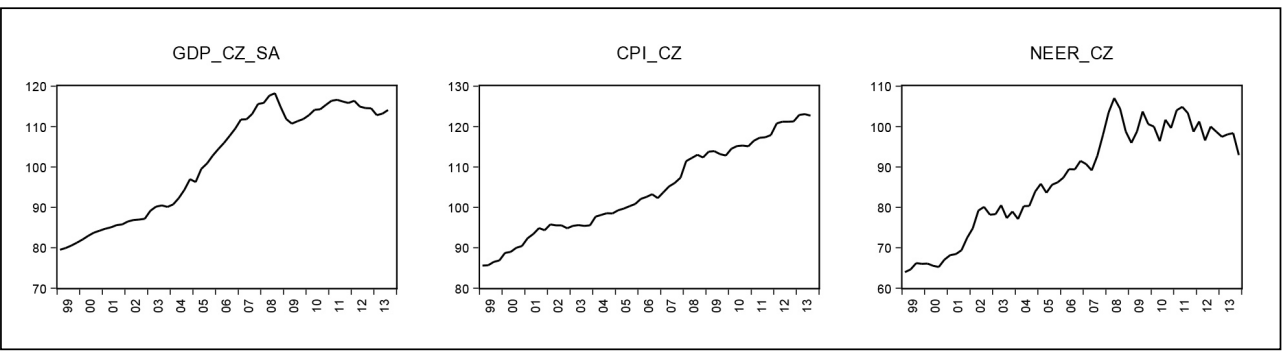

Source: own calculations, Eurostat [16]

Evolution of the observed endogenous variables for the whole EMU showed a similar trend as the evolution of endogenous variables in the Czech Republic (Fig. 3). As for the evolution of the EMU's GDP, it indicated an increasing trend until 2007, interrupted only by the impact of the global economic crisis in 2008. Some EMU countries even suffered a decline in the GDP compared to 2007. After 2008, the GDP growth trend slowly recovered, although 2012 brought again a more pronounced slowdown as a reaction on the situation prevailing in the EMU at the time. Similarly to GDP, inflation was rather stable until 2007; afterwards its evolution became more volatile. The nominal effective exchange rate of the EMU was marked with a general trend of a gradual strengthening, interrupted only by shorter temporary periods of NEER's depreciation. The most significant weakening of the NEER can be observed in the years affected by the global crisis. 

Fig. 3: Evolution of GDP (index, 2005=100), index of consumer prices (index),
NEER (index)

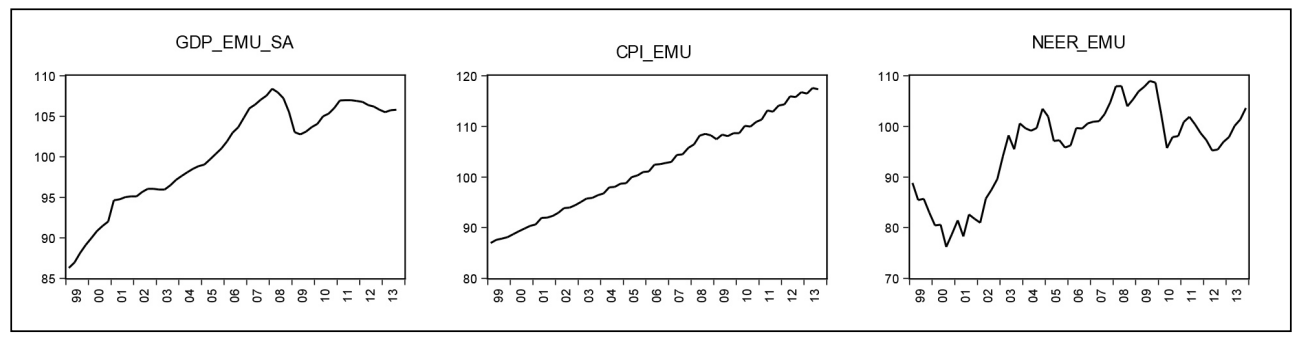

Source: own calculations, Eurostat [16]

\subsection{Tests - The Verification of the Basic Assumptions of the Model}

Before using data for econometric modelling, it is necessary to examine their stationarity that was verified through unit roots testing. We used Dickey-Fuller test (Augmented Dickey-Fuller test, ADF) and Phillips-Perron test (PhillipsPerron test, PP). Both tests verify the null hypothesis of the existence of a unit root. If the hypothesis were confirmed, it would mean that the time series are non-stationary. Observed time series were mostly non-stationary at values, therefore it was necessary to test them for the stationarity also at their first differences. Here, the stationarity was confirmed and the null hypothesis of the unit root presence was rejected (Tab. 1).

\section{Tab. 1: The results of unit root tests (1999Q1-2013Q4)}

\begin{tabular}{l|c|c|c|c|c|c|c|c} 
Czech Republic & $\begin{array}{c}\text { PRIBOR } \\
\text { ADF }\end{array}$ & $\begin{array}{c}\text { PRIBOR } \\
\text { PP }\end{array}$ & $\begin{array}{c}\text { GDP } \\
\text { ADF }\end{array}$ & $\begin{array}{c}\text { GDP } \\
\text { PP }\end{array}$ & $\begin{array}{c}\text { NEER } \\
\text { ADF }\end{array}$ & $\begin{array}{c}\text { NEER } \\
\text { PP }\end{array}$ & $\begin{array}{c}\text { CPI } \\
\text { ADF }\end{array}$ & $\begin{array}{c}\text { CPI } \\
\text { PP }\end{array}$ \\
\hline values & -1.995 & -2.429 & -1.457 & -1.452 & -1.727 & -1.827 & -0.143 & -0.357 \\
\hline 1st diff. & $-5.086^{\star}$ & $-5.086^{\star}$ & $-4.781^{\star}$ & $-4.836^{\star}$ & $-7.298^{\star}$ & $-7.288^{\star}$ & $-2.76^{\star \star *}$ & $-7.595^{\star}$ \\
\hline EMU & $\begin{array}{l}\text { EURIBOR } \\
\text { ADF }\end{array}$ & $\begin{array}{c}\text { EURIBOR } \\
\text { PP }\end{array}$ & $\begin{array}{c}\text { GDP } \\
\text { ADF }\end{array}$ & $\begin{array}{c}\text { GDP } \\
\text { PP }\end{array}$ & $\begin{array}{c}\text { NEER } \\
\text { ADF }\end{array}$ & $\begin{array}{c}\text { NEER } \\
\text { PP }\end{array}$ & $\begin{array}{c}\text { CPI } \\
\text { ADF }\end{array}$ & $\begin{array}{c}\text { CPI } \\
\text { PP }\end{array}$ \\
\hline values & -1.573 & -1.379 & -2.327 & -2.577 & -1.116 & -1.256 & $-0.167^{\star *}$ & $-0.188^{\star \star}$ \\
\hline 1st diff. & $-4.893^{\star}$ & $-4.950^{\star}$ & $-3.860^{\star}$ & $-3.839^{\star}$ & $-6.885^{\star}$ & $-6.896^{\star}$ & $-4.199^{\star}$ & $-11.94^{\star}$ \\
\hline
\end{tabular}

Note: Data represent result of t-statistics. Null hypothesis cannot be rejected at $1 \%$ significance level $\left({ }^{\star}\right)$, at $5 \%$ significance level $\left({ }^{\star \star}\right)$, at $10 \%$ significance level $\left({ }^{\star \star \star}\right)$.

Source: own calculations

When testing time series, it is also necessary to determine whether observations are not mutually correlated. The presence of the residual autocorrelation was checked by using LM test as well as the corellogram, which confirmed that the residuals can be regarded as mutually uncorrelated. Jarque-Berra test was used to test the normality of residuals. Based on the test results, it can be concluded that the residuals are from the normal distribution.
Testing for the cointegration verifies the existence of stable long-term relations between endogenous variables of the model. For this purpose, Johansen test was used with a number of delays equal to 5 (determined according to AIC, LR and FPE information criteria) for both the EMU and the Czech Republic. The results of both test statistics (trace test and maximum eigenvalue statistics) did not confirm the presence of cointegrating equation (Tab. 2) and thus a VAR approach can be applied. 
Tab. 2: The results of cointegration tests (1999Q1-2013Q4)

\begin{tabular}{|c|c|c|c|c|}
\hline \multicolumn{5}{|c|}{ Czech Republic } \\
\hline equations & Trace Stat. & 0.05 critical value & Max Eigenvalue & 0.05 critical value \\
\hline none* & 20.13204 & 29.79707 & 13.88818 & 21.13162 \\
\hline at most 1 & 6.243856 & 15.49471 & 3.760787 & 14.26480 \\
\hline \multicolumn{5}{|c|}{ EMU } \\
\hline equations & Trace Stat. & 0.05 critical value & Max Eigenvalue & 0.05 critical value \\
\hline none* & 25.85441 & 29.79707 & 19.00112 & 21.13162 \\
\hline at most 1 & 6.853290 & 15.49471 & 6.849003 & 14.26460 \\
\hline
\end{tabular}

Source: own calculations

The stability of the selected model was evaluated and confirmed through AR Root Test. Based on all results (unit root test and cointegration) a VAR model was estimated. Subsequently, this model allowed deduction of impulse-response functions as well as the variance decomposition for both the EMU and the Czech Republic.

\subsection{Discussion of Results}

The estimated VAR model allows to deduce the impulse-response functions (IRF) for each of the endogenous variables. We focused only on the observations of variables' responses to changes in interest rate PRIBOR for the Czech Republic and EURIBOR for the EMU. We considered a one-time positive interest rate shock which represents a monetary tightening.
Based on the theory, it can be expected that a monetary tightening (increase in short-term interest rate) will be followed by a decrease in total product, the price level, and the appreciation of the exchange rate (increase of exchange rate) shortly thereafter.

The graphs for the years 1999-2013 (Fig. 4) show as expected, the decrease of the product. However, the product did not respond immediately but with a delay of approximately three quarters. NEER responded by deterioration in the short term, what may be related to the higher volatility of bilateral exchange rates of the Czech Crown against foreign currencies since 2008. Similarly, the price level did not react as anticipated. Its response was a very mild and delayed by approximately two quarters.

\section{Fig. 4: \% Reactions of GDP, CPI and NEER to 1\% change of PRIBOR (1999Q1-2013Q4)}

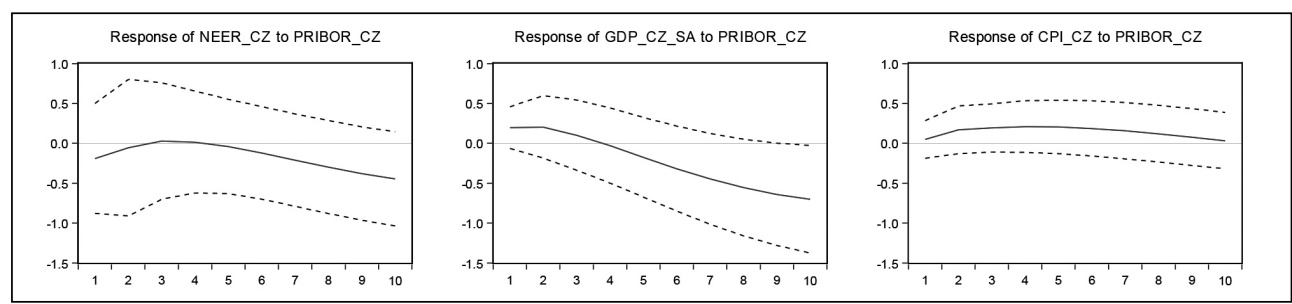

Source: own calculations

In the shorter period when crisis still did not affect the macroeconomic situation, the endogenous variables' responses to sudden interest rate shock were much closer to theoretical expectations (Fig. 5) for the first two variables. The product reacts similarly as in the longer period, i.e. by a decrease with time lag of three quarters. The NEER's reaction leads towards a very modest and short-term recovery but only after two quarters. The price level equally does not respond as expected, to the shock in the short-term interest rates. 
Based on these findings, it could be said that the impact of interest rate shock on the variables studied over a longer period 19992013 (with the impact of the crisis) was different from the development in a shorter period (with no crisis) only to a small extent. Initial suppositions based on theoretical assumptions were fulfilled in a shorter period of 1999-2008 for the NEER and the GDP. The reaction of the price level was in neither of the cases in accordance with the expected evolution. We cannot therefore definitively state that the transmission from monetary policy measures to the real macroeconomic variables was significantly disturbed by the crisis.

\section{Fig. 5: \% Reactions of GDP, CPI and NEER to 1\% change of PRIBOR (1999Q1-2008Q4)}

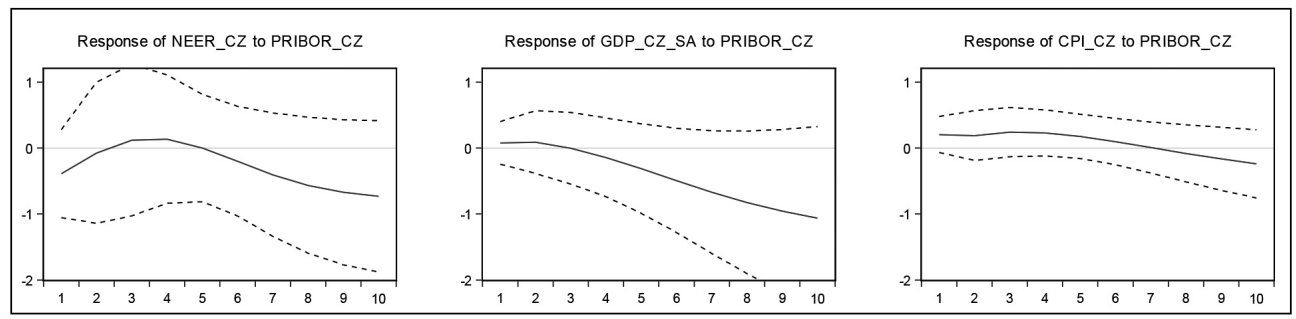

Source: own calculations

The evolution of IRF functions for the EMU in the period of 1999-2013 is shown by Fig. 6. The responses of the GDP and the price level were contrary to initial expectations. The product starts to decline with a more significant delay of five quarters. The nominal effective exchange rate reacts by a depreciation, as in the case of the Czech Republic. These results may be explained by the composition of NEER which takes into account transactional elements (effect on real output) and trade relations of the country to a greater extent than just the effects of short-term interest rates. The heterogeneity of the EMU can also play a certain role as it caused that the macroeconomic effects of the crisis for various countries differed.

The reactions of endogenous variables in a shorter period of 1999-2008 (Fig. 7) are very similar to the reactions over a longer period. Evolution of IRF functions for GDP and $\mathrm{CPI}$ is almost identical. In case of NEER, a depreciation of the exchange rate can be observed over the first four quarters

The comparison of the reactions studied for longer and shorter periods show in neither of the cases a significant distortion of transmission of monetary measures to the real macroeconomic variables due to the crisis.

\section{Fig. 6: \% Reactions of GDP, CPI and NEER to 1\% change of EURIBOR (1999Q1-2013Q4)}

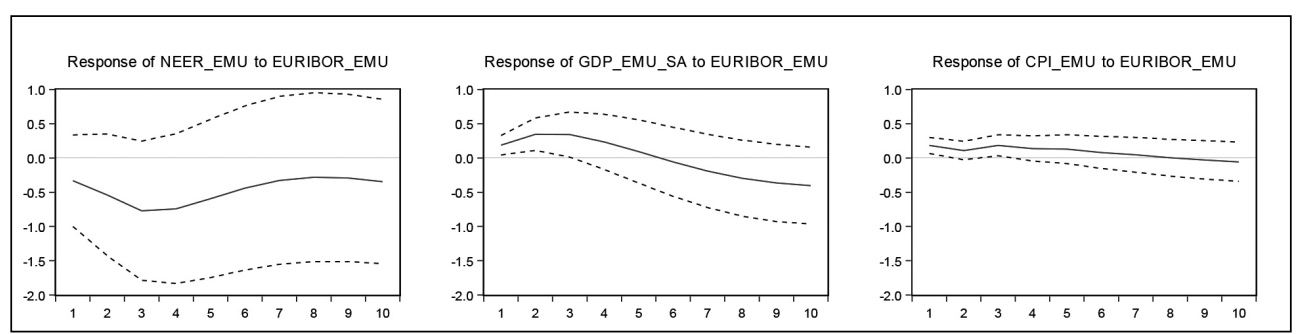



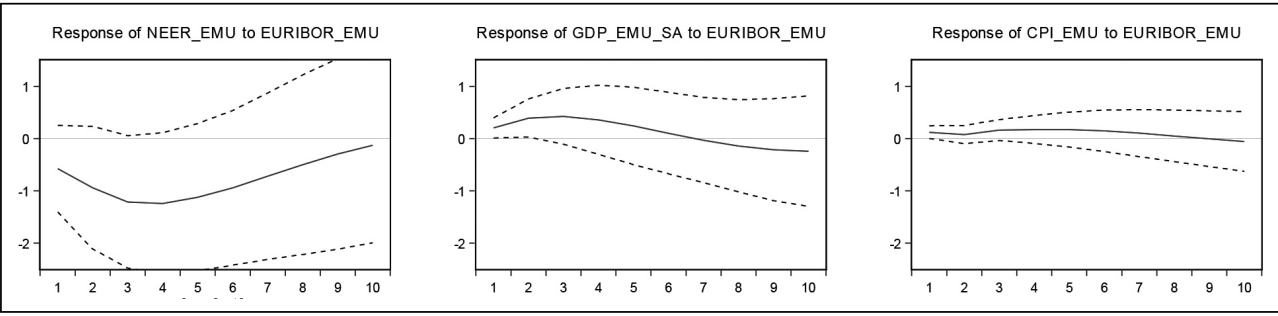

Source: own calculations

Comparison of the reactions of variables 1999-2013 in the Czech Republic and in the EMU suggests that the effects of positive interest rate shock are very similar for the product and the price level. Within a shortened pre-crisis period of 1999-2008 a different reactions can be observed for the nominal effective exchange rate; Czech Republic's NEER is closer to the anticipated response. Yet, it cannot be confirmed definitively that the crisis disrupted the transmission process from monetary measures to the real macroeconomic variables neither for the Czech Republic nor in the case of the EMU. Another important issue is a fact that the effectiveness of the short-term interest rate in affecting the price level has proved to be relatively weak. Based on these findings we can conclude that in the both observed cases the effect of exchange rate puzzle and the price puzzle appeared, as described, for example by Arnoštová and Hurník [2], Balke and Emery [7] or Castelnuovo and Surico [12].

\subsection{The Results of Variance Decomposition of Endogenous Variables}

Based on the estimated model it was possible to continue with the variance decomposition of the endogenous variables. Tab. 3 shows the contributions of the changing interest rate PRIBOR to the variability of the GDP, the price level and the nominal effective exchange rate for the Czech Republic over the period 1999-2013.
It can be concluded that the change of PRIBOR has a significant impact on the variability of the GDP $(15.5 \%)$ but only with a time delay. The reaction is weaker for the price level $(9.23 \%)$. Similarly, in the case of the nominal effective exchange rate the effect of changes in interest rates has a weaker momentum and accelerates with a time delay $(7.23 \%)$. In percentage terms, the effects of the PRIBOR can be described as "the strongest" for the GDP. It can therefore be concluded that the responses of variables on the unexpected increase in short-term interest rates are weak and delayed.

Based on the variance decomposition of the endogenous variables in the EMU for the period of 1999-2013 we can say that the contribution of changes in EURIBOR to the GDP's variability in the whole EMU was significant, especially at the beginning of the period but with the lag of two quarters (17.18\%). This contribution was weakening with the increasing time interval. The interest rate shock also had a fast impact on the price level when its effect increased significantly during the first three quarters (18.33\%). For NEER the greater impact of interest rate shock started to show only with the delay of four quarters and peaked after six quarters (9.58\%). (Tab. 3)

The decomposition of variance calculated for the period of 1999-2013, showed in case of the EMU statistically significant contributions of interest rate changes to the variability of all studied endogenous variables but with different time shifts. 
Tab. 3: Variance decomposition of endogenous variables (1999Q1-2013Q4)

\begin{tabular}{c|c|c|c|c|c|c|c}
\multicolumn{5}{c}{ Czech Republic } & \multicolumn{4}{c}{ EMU } \\
\hline Period & $\begin{array}{c}\text { GDP_ } \\
\text { CZ_SA }\end{array}$ & CPI_CZ & $\begin{array}{c}\text { NEER_ } \\
\text { CZ }\end{array}$ & Period & $\begin{array}{c}\text { GDP_ } \\
\text { EMU_SA }\end{array}$ & CPI_EMU & $\begin{array}{c}\text { NEER_ } \\
\text { EMU }\end{array}$ \\
\hline $\mathbf{1}$ & 0.609505 & 5.690250 & 3.529536 & $\mathbf{1}$ & 11.23519 & 15.60565 & 1.732183 \\
\hline $\mathbf{2}$ & 0.703338 & 6.031570 & 1.532985 & $\mathbf{2}$ & 17.18430 & 15.72192 & 3.378863 \\
\hline $\mathbf{3}$ & 0.424459 & 7.504819 & 1.180926 & $\mathbf{3}$ & 16.97604 & 18.33384 & 6.345194 \\
\hline $\mathbf{4}$ & 0.720938 & 8.770392 & 1.162716 & $\mathbf{4}$ & 14.35716 & 17.57779 & 8.435717 \\
\hline $\mathbf{5}$ & 1.993569 & 9.231845 & 1.120073 & $\mathbf{5}$ & 11.72825 & 16.46137 & 9.390236 \\
\hline $\mathbf{6}$ & 4.265255 & 8.962689 & 1.313075 & $\mathbf{6}$ & 10.08913 & 14.66306 & 9.587176 \\
\hline $\mathbf{7}$ & 7.120639 & 8.320081 & 2.145866 & $\mathbf{7}$ & 9.895306 & 12.94677 & 9.401672 \\
\hline $\mathbf{8}$ & 10.10931 & 7.795855 & 3.649641 & $\mathbf{8}$ & 11.04064 & 11.50375 & 9.089625 \\
\hline $\mathbf{9}$ & 12.93624 & 7.679011 & 5.497954 & $\mathbf{9}$ & 13.07762 & 10.44981 & 8.809713 \\
\hline $\mathbf{1 0}$ & 15.51228 & 8.063177 & 7.324786 & $\mathbf{1 0}$ & 15.49464 & 9.794460 & 8.673513 \\
\hline
\end{tabular}

Note: Cholesky ordering for the Czech Republic: PRIBOR_CZ NEER_CZ GDP_CZ_SA CPI_CZ; Cholesky ordering for the EMU: EURIBOR_EMU NEER_EMU GDP_EMU_SA CPI_EMU

Source: own calculations

When comparing the results of the variance decomposition for the Czech Republic we can observe the lower contributions of changes in interest rate to variability of variables. The interest rate channel did not revealed, particularly in case of the Czech Republic; a strong and stable effect on the observed variables. Similar findings can be found in the analysis of Holub [21] who states that the impact of interest rates on the deviations in inflation was close to statistical significance, with the exchange rate being the most important factor. Bisová [10] also confirms a stronger and more stable position of the exchange rate channel within the transmission mechanism in the Czech Republic in comparison with the interest rate channel.

\section{Conclusion}

The recent global crisis has renewed interest in studying the transmission mechanism of monetary policy. Many authors noticed that the crisis affected mostly the traditional interest rate channel. The crisis has also renewed debates of the joining the EMU and the advantages of single monetary policy as a tool for the macro-economic regulation and mitigation of shocks. Unfavourable developments after
2008 still verify the ability of monetary policy to mitigate negative impacts. This can be seen in the context of common monetary policy effects and deepening asymmetries between member countries. It is possible to evaluate the success of a single monetary policy of small and open, non-member country in influencing macroeconomic situation. From the point of view of the central authorities of these countries, e.g. the Czech Republic, it seems therefore important to preserve an independent monetary policy.

Our analysis was focused on monitoring the operation of monetary policy through interest rate transmission channel with the use of the basic variables: GDP, price level and exchange rate, i.e. the variables that central banks typically use within their monetary rules. The aim of the analysis was to verify the similarity of the monetary transmission process through this channel in case of EMU and the Czech Republic. We supposed that the negative evolution related to the crisis can disrupt the transmission of monetary policy measures to macroeconomic variables, therefore the impacts of monetary policy changes are transmitted to the observed economic variables only partially or with significant lags. 
The estimations were made using a Vector Autoregression - a VAR model, which is often used to evaluate the effects of monetary policy and effectiveness of transmission channels. It also allows comparing the results obtained for the different countries. The model was estimated for two different time periods: shorter 1999-2008 and longer 1999-2013, including the economic crisis and the development that followed. The same method used for different periods enabled to analyse the impact of the crisis on the monetary policy transmission process, namely the impact on product, prices and exchange rates. Based on the observed results it can be concluded that the product and price level responses to the positive interest rate shock in the EMU and in the Czech Republic are very similar within entire period 1999-2013. In the shortened, precrisis period 1999-2008 a different reaction of the nominal effective exchange rate could be observed, which in the case of the Czech Republic is closer to the expected response. It cannot be clearly stated that the crisis disrupted the transmission process of monetary measures to the real macroeconomic variables neither in the Czech Republic nor in the EMU. The interest rate channel has not confirmed strong and stable effect on the observed variables.

This article was elaborated within the project VEGA no. 1/0892/13.

\section{References}

[1] ANGELONI, I., KASHYAP, A. K., MOJON, B., TERLIZZESE, D. Monetary transmission in the euro area: does the interest rate channel explain all? The National Bureau of Economic Research. 2003. Working paper No. 9984. doi: 10.3386/w9984.

[2] ARNOŠTOVÁ, K., HURNÍK, H. The monetary transmission mechanism in the Czech Republic (evidence from VAR analysis). Czech National Bank. Working Paper Series 4/2005.

[3] ARTL, J., MANDEL, M. Je možné předpovídat repo sazbu ČNB na základě zpět hledícího měnového pravidla? Politická ekonomie. 2012, Iss. 4, pp. 484-504. ISSN 0032-3233.

[4] BABECKÁ KUCHARČUKOVÁ, O., FRANTA, M., HÁJKOVÁ, D., KRÁL, P., KUBICOVÁ, I., PODPIERA, A., SAXA, B. What do we know about monetary policy transmission in the Czech Republic: Collection of Empirical Results. Czech National Bank. CNB Research and Policy Notes $1 / 2013$.
[5] BADARAU, C., LEVIEUGE, G. Assessing the effects of financial heterogeneity in a monetary union a DSGE approach. Economic Modelling. 2011, Vol. 28, Iss. 6, pp. 2451-2461. ISSN 02649993. doi:10.1016/j.econmod.2011.06.016.

[6]BANKFORINTERNATIONALSETTLEMENTS. Statistical data on evolution of NEER for CZK and EUR, period 1999-2014 [online]. Bank for International Settlements, 2013 [cit. 2013-1115]. Available from: http://www.bis.org/.

[7] BALKE, N. S., EMERY, K. M. Understanding the price puzzle. Economic Review - Fourth Quarter. Federal Reserve Bank of Dallas, 1994. 12 p. Available also from: https://www.dallasfed. org/assets/documents/research/er/1994/ er9404b.pdf.

[8] BARRAN, F., COUDERT, V., MOJON, B. The transmission of monetary policy in the European countries. Centre d'études prospectives et d'informations intranationales, 1996. Document de travail No. 96-03.

[9] BARTÓKOVÁ, L. The evolution of the monetary policy transmission mechanism of V4 countries. E+M Ekonomie a Management. 2010, Vol. 13, Iss. 2, pp. 6-18. ISSN 1212-3609. [10] BISOVÁ, S. Analýza monetární politiky pomocí modelů VAR - aplikace na českou ekonomiku. In: DOUCEK, P. (ed.). Vědecká konference doktorského studia FIS 2013. Praha: Oeconomica, 2013, pp. 106-117. ISBN 978-80-245-1924-1.

[11] BRISSIMIS, N. S., SKOTIDA, I. Optimal monetary policy in the euro area in the presence of heterogeneity. Journal of International Money and Finance. 2008, Vol. 27, Iss. 2, pp. 209-226. ISSN 0261-5606. doi:10.1016/j. jimonfin.2007.12.007.

[12] CASTELNUOVO, E., SURICO, P. The price puzzle: fact or artefact? Bank of England, 2006. Working Paper No. 288. ISSN 1749-9135. doi:10.2139/ssrn.1513241.

[13] CZECH NATIONAL BANK. Statistical data on evolution of interest rates, period 1999-2014 [online]. Prague: Czech National Bank, 2013 [cit. 2013-11-18]. Available from: http://www. cnb.cz.

[14] DEMCHUK, O., LYZIAK, T., PRZYSTUPA, J., SZNAJDERSKA, A., WRÓBEL, E. Monetary policy transmission mechanism in Poland. What do we know in 2011? National Bank of Poland, 2012. Working Paper No. 116. ISSN 2084-624X. [15] ĎURČOVÁ, J. Režim inflačného cielenia a konvergenčná stratégia. Biatec. 2008, Vol. 16, Iss. 5, pp. 26-29. ISSN 1335-0900. 
[16] EUROSTAT. Statistical data on evolution of GDP, consumer price index, period 19992014 [online]. Eurostat, 2013 [cit. 2013-11-18]. Available from: http://epp.eurostat.ec.europa.eu. [17] EUROPEAN CENTRAL BANK. Statistical data on evolution of interest rates, period 19992014 [online]. European central bank, 2013 [cit. 2013-11-15]. Available from: https://www.ecb. europa.eu.

[18] ÉGERT, B., CRESPO-CUARESMA, J., REININGER, T. Interest rate pass-through in central and Eastern Europe: Reborn from ashes merely to pass away? Journal of Policy Modeling. 2007, Vol.29, Iss.2, pp. 209-225. ISSN 0161-8938. doi:10.1016/j.jpolmod.2007.01.005. [19] GERLACH, S., SMETS, F. The monetary transmission mechanism: Evidence From the G-7 countries. Bank for International Settlements, 1995. Working Paper No. 26.

[20] GONDA, V. Alternatívne režimy protiinflačnej politiky a cielenie inflácie. Národohospodářský obzor. 2002, Iss. 12, pp. 14-26. ISSN 1213-2446. [21] HOLUB, T. Príćiny odchylek inflace od cílů ČNB - empirická analýza. Vyhodnocení plnění inflačních cílů ČNB v letech 1998-2007. Prague: Czech National Bank, 2008. ISBN 97880-87225-10-3.

[22] INTERNATIONAL MONETARY FUND. Financial Crises: Causes and Indicators [online]. International Monetary Fund, 1998 [cit. 2013-11-13]. Available from: http://www.imf.org/ external/pubs/ft/weo/weo0598/.

[23] INTERNATIONAL MONETARY FUND. Global financial stability report. The quest for lasting stability. IMF, 2012. 192 p. ISBN 97861635-247-9.

[24] JAKUBÍKOVÁ, E., MIHÓKOVÁ, L. Impact of the Government debt on the macroeconomic development of the Slovak and Czech Republic. Analysis of the Impact of the Economic Crisis on Public Finances. $1^{\text {st }}$ ed. Praha: Wolters Kluwer, 2011. 316 p. ISBN 978-80-7357-763-6. [25] JIMÉNEZ-RODRÍGUEZ, R., MORALESZUMAQUERO, A., ÉGERT, B. The VARying Effect of Foreign Shocks in Central and Eastern Europe. William Davidson Institute Working Papers Series wp989, 2010. William Davidson Institute at the University of Michigan.

[26] KRAFT, J., BEDNÁŘOVÁ, P., LUNGOVÁ, M., NEDOMLELOVÁ, I., SOJKOVÁ, L. Hospodářská krize: vybrané makroekonomické souvislosti s projekcí na úrovni regionů. 1. vyd. Brno: Tribun EU, 2010. 157 s. ISBN 978-807372-678-2.
[27] LUNGOVÁ, M. Economic Crisis 20082009: Analysis of Its Causes. E+M Ekonomie a Management. 2011, Vol. 14, Iss. 2, pp. 22-30. ISSN 1212-3609.

[28] LYZIAK, T., PRZYSTUPA, J., STANISLAWSKA, E., WRÓBEL, E. Monetary policy transmission disturbances during the financial crisis: a case of emerging market economy. National Bank of Poland, 2011.

[29] MISHKIN, F. S. Monetary policy strategy. Cambridge (MA): The MIT Press, 2009. ISBN 978-0-262-13482-8.

[30] MISHKIN, F. S. Is monetary policy effective during financial crises? The National Bureau of Economic Research, 2009. Working paper series 14678. doi:10.3386/w14678.

[31] MOJON, B., PEERSMAN, G. A VAR description of the effects of monetary policy in the individual countries of the euro area. European Central Bank, 2001. Working Paper No. 92. Available also from: http://www.ecb. europa.eu/pub/pdf/scpwps/ecbwp092.pdf.

[32] MOONS, C., GARRETSEN, H., VAN AARLE, B., FORNERO, J. Monetary policy in the New-Keynesian model: An application to the Euro Area. Journal of Policy Modeling. 2007, Vol. 29, Iss. 6, pp. 879-902. ISSN 0161-8938. doi:10.1016/j.jpolmod.2007.05.013.

[33] SINIČÁKOVÁ, M., PAVLIČKOVÁ, V. Monetary Rules and Their Application in Times of Economic Crisis and in the Euro Area. $E+M$ Ekonomie a Management. 2011, Vol. 13, Iss. 3, pp. 16-29. ISSN 1212-3609.

[34] ŠMÍDKOVÁ, K. The transmission mechanism policy at the beginning of the third millennium [online]. 2002 [cit. 2013-11-15]. 25 pp. Available from: http://128.118.178.162/ eps/mac/papers/0403/0403012.pdf.

[35] ZAMRAZILOVÁ, E. Měnová politika: Staré lekce, nové výzvy. Politická ekonomie. 2011, Vol. 59, Iss. 1, pp. 3-21. ISSN 0032-3233.

Ing. Ludmila Bartóková, PhD.

Technical University of Košice

Faculty of Economics

Department of Economic Theories ludmila.bartokova@tuke.sk

Ing. Júlia Ďurčová, PhD. Technical University of Košice Faculty of Economics Department of Economic Theories julia.durcova@tuke.sk 


\title{
EFFECTIVENESS OF THE MONETARY POLICY IMPLEMENTATION IN THE CONTEXT OF CRISIS: USE OF SHORT-TERM INTEREST RATE IN THE CZECH REPUBLIC AND EMU
}

\author{
Ludmila Bartóková, Júlia Ďurčová
}

Focus on monetary policy transmission mechanism has regained its importance especially in regards to financial and debt crisis. Negative developments after 2008 still verify the ability of monetary policy to mitigate its impacts. In EMU, it can be seen in the case of the effects of single monetary policy and the deepening of the asymmetries between member countries. This can be compared to the case of the monetary policy efficiency in small and open non-member country and its influence on macroeconomic developments.

This paper is focused on the analysis of transmission process of monetary policy through the interest rate channel in EMU as well as in a non-member country, namely in Czech Republic. The aim of the analysis was to verify the similarity of reaction in case of monetary policy shock. The results for Czech Republic were compared to results for overall EMU. The focus was predominantly on interest rate channel of monetary transmission process and its impact on inflation, nominal effective exchange rate and gross domestic product, the variables that are typically used in central banks' monetary rules. We also assumed that negative developments related to the crisis can distort the transmission of monetary policy effects on macroeconomic variables and that the impact of monetary policy changes is transmitted to the economic variables only partially or significantly lagged. The effects of interest rate shocks on selected variables were identified by estimating VAR model that uses Cholesky decomposition of innovations; the most widely used empirical methodology for analysing the transmission mechanism of monetary policy. The results show that the reactions of the product and the price level to positive interest rate shock are very similar for Czech Republic as well as for EMU throughout the investigated period 1999-2013. However, we cannot definitively affirm that the crisis disrupted the transmission process from monetary measures to analysed macroeconomic variables as shown in the cases of Czech Republic and EMU. Interest rate channel has not shown particularly strong and stable influence on the observed variables neither for Czech Republic, nor for EMU.

Key Words: Interest rate channel, monetary policy shock, EMU, Czech Republic, economic crisis, VAR model.

JEL Classification: E43, E52, C32.

DOI: 10.15240/tul/001/2015-1-001 